\title{
Kulturní kontakty a kolaps království Benin
}

\author{
BARBORA PŮTOVÁ* - VÁCLAV SOUKUP** \\ Cultural Contacts and the Fall of the Benin Empire
}

\begin{abstract}
This study deals with historic cultural contacts between Europeans and the Benin Empire, one of the most significant native African cultural centres between the 15th and the 17th century. The study focuses particularly on the development of the Benin Empire on the background of acculturation and diffusion of European cultural elements and complexes. The study describes the first contacts between Europeans and the Benin Empire and the subsequent business activities, including slave trade. Special attention is paid to European colonial expansion that culminated in the 1897 British invasion which led to the conquest of the Benin City. The aim of the study is to draw attention to the role of the exogenous cultural change and acculturation processes, which caused the fall of once a socially, economically, politically and culturally stable African empire.
\end{abstract}

Keywords: Benin Empire; Benin City; cultural and business contacts; invasion; conquest

DOI: $10.14712 / 23363525.2015 .5$

\section{Úvod}

Africké království Benin se zrodilo v pásmu tropického deštného pralesa na území dnešní jihozápadní Nigérie. Počátky Beninu sahají do 12. století, ale největší rozkvět tohoto království nastal v 15. až 17. století. V tomto období vnitřní sociální, ekonomická a politická stabilita země umožnila vládcům Beninu dále rozšiřovat hranice svého království a efektivně využívat lidské a přírodní zdroje ovládaného teritoria. Bohatství tohoto království ale již na sklonku 15. století vyvolalo zájem Evropanů usilujících o navázání obchodních a ekonomických kontaktů. Beninské království se tak ocitlo v ohnisku celé řady kulturních změn vyvolaných difuzí evropských kulturních prvků a komplexů a s ní související migrací obchodníků, kteří se zde pokoušeli výhodně nakoupit a poté se ziskem prodat na Západě ceněné africké suroviny a další obchodní komodity. Zájmy Evropanů o Benin „měly široký záběr přes obchod, misionářské úsilí až po imperiální ambice“ [Ryder 1969: x]. Místem, kam směřovali evropští obchodníci, diplomaté, vojáci i misionáři, bylo sídlo beninských vládců, město Benin. Příchod Evropanů do tohoto města byl ale předzvěstí sociokulturní změny, jejímž výsledkem byl kolaps beninské kultury, způsobený koloniální expanzí západní civilizace.

\footnotetext{
* PhDr. Barbora Půtová, Ph.D. et Ph.D., Ústav etnologie, Filozofická fakulta Univerzity Karlovy v Praze, Celetná 20, 11642 Praha 1. E-mail: barbora.putova@ff.cuni.cz.

** PhDr. Václav Soukup, CSc., Ústav etnologie, Filozofická fakulta Univerzity Karlovy v Praze, Celetná 20, 11642 Praha 1. E-mail: vaclav.soukup@ff.cuni.cz.
} 


\section{Město Benin jako ohnisko kulturních kontaktů}

Dějiny království Benin jsou úzce spjaty s jeho stejnojmenným hlavním městem. Mocenský, náboženský, ekonomický i urbanistický význam města Benin začal narůstat v průběhu 13. století. Ve 14. století byl již Benin politickým a kulturním centrem expandujícího království. K největšímu rozkvětu tohoto města ale došlo v 15. až 17 . století, kdy se stalo správním střediskem rozsáhlého území ovládaného beninskými vladaři. Město Benin se zrodilo v oblasti tropického deštného pralesa. Jeho okraj protínala řeka Ikpoba, zatímco jižně od města se nacházely hlavní vodní toky umožňující lodní dopravu - řeka Benin (Formosa), Forcados, Warri a Escravos [Kingsley 2010]. Město Benin z tohoto hlediska zaujímalo strategickou obchodní polohu, zahrnující tři významné úseky říčního systému, jenž spojoval vnitrozemí a mořské pobřeží. Benin byl opevněn hliněnými hradbami, které tvořil vysoký násep, doplněný hlubokým př́ikopem (iya). Fortifikační systém zahrnoval vnitřní a vnější prstence hradeb, jež měly defenzivní obrannou funkci. Původní výše náspu společně s příkopem činila více než 18 metrů. Budování beninského fortifikačního systému údajně zahájil ve 2. polovině 13. století oba Oguola (1274-1287). Ten nejdřive nechal postavit první a druhý příkop a poté rozkázal vybudovat dalších dvacet př́kopů nejen kolem města Benin, ale také v jeho okolí. Městské opevnění se tak z Beninu rozrostlo všemi směry a zasahovalo až do venkovských oblastí [Darling 1976]. Výstavbu komplexního systému hradeb a příkopů završil kolem roku 1460 oba Ewuare Veliký (1440-1473). Součástí městského opevnění bylo v té době devět dřevěných bran (urho), které se na noc uzavíraly. Brány chránila ozbrojená stráž kontrolující prrístup do města a vybírající daně [Ben-Amos 1995]. Beninský fortifikační systém včetně městských bran poprvé popsal na konci 15. století portugalský mořeplavec Duarte Pacheco Pereira (1460-1533). „Město samotné je jakýmsi svazkem pospojovaným branami; nemá žádné zdi, ale je obklopeno velkým př́kopem, velice širokým i hlubokým, který je dostačující pro jeho obranu“ [Pereira 1967: 125].

Oba Ewuare město Benin teritoriálně rozdělil na jihozápadní městskou část (ogbe) a severovýchodní městskou část (ore). Na menším jihozápadním území se nacházel královský palác, jenž představoval politické, náboženské a duchovní centrum království. Budova paláce byla obklopena zdí a od severovýchodní části ji oddělovala široká ulice. Palác, který se rozkládal na čtvercové ploše $350 \times 620$ metrů, zahrnoval kromě soukromých královských budov a královského harému také uvítací dvory a sídla palácových hodnostářů. V severovýchodní městské části se rozkládala čtvrt’ městských hodnostářu. Sídlily zde také cechy, které měly k dispozici přibližně 40 až 50 řemeslnických hliněných budov.

První královský palác postavil již kolem roku 1255 oba Ewedo (1260-1274). V průběhu následujících staletí byl ale palác dále rozšiřován, upravován a přestavován. Vnější zdi paláce byly téměř sedm metrů vysoké a u své základny více než metr silné. Př́istup do paláce byl př́ísně kontrolován, nebot' některé jeho části byly určeny pouze pro vybrané hosty nebo palácové rodinné příslušníky. Dveře a trámy královských místností často zdobily ručně zhotovené bronzové reliéfní ozdoby, nebo byly vykládány zrcadlem. Součástí výzdoby palácových dveří byly také figurativní slonovinové zástrčky a jemně zpracované klíče, které byly duchovním symbolem a současně metaforickým vyjádřením ochrany palácových prostor. 
V paláci ${ }^{1}$ se nacházel asi 50 metrů dlouhý vnitřní dvưr (atrium), jenž byl po stranách zastřešený. V jeho středu byl otvor (impluvium), pod nímž byla zapuštěna nádržka (compluvium) sloužící k zachycení deštové vody. Vnitřní dvůr po stranách obklopovala otevřená sloupová galerie (peristyl). Toto architektonické řešení vnitřního prostoru umožnilo vpouštět do většiny z palácových interiérů světlo a vzduch bez užití oken. Sloupy, které podpíraly střechu galerií, byly původně dřevěné. Od 19. století ale byla k jejich zhotovení používána také hlína. Vnitřní dvory byly vzájemně propojeny chodbami a průchody [PittRivers 1900; Dark 1973; Skinner 1973; Aniakor 1978; Dmochowski 1990]. Atria představovala základní elementy palácové architektury. Některé obklopovaly galerie se zahloubenými výklenky, jež sloužily jako místo k odpočinku nebo ke spánku. Součástí atria byly také oltáře, jež zdobily „velké bronzy a ohromné vyřezávané sloní kly. (...) Takové byly svatyně zesnulých králů Beninu“ [Allman 1898: 44].

Město Benin v dobách největšího rozkvětu protínala sít dlouhých a rovných ulic, lemovaných domy, které byly postaveny blízko sebe. Nádheru hlavního města beninského království popisovali již od konce 15. století evropští obchodníci a cestovatelé. Na Beninu je překvapila nejenom jeho výstavnost a rozlehlost, ale také jeho urbanistická koncepce. Portugalci město Benin přirovnávali k Lisabonu, Holand’ané k Amsterdamu nebo Antverpám, Italové k Florencii a Španělé k Madridu. Holandský mořeplavec Dierick Ruiters, který navštívil město Benin roku 1602, popsal jeho hlavní „ohromně širokou ulici, nedlážděnou, jež může být sedmkrát nebo devětkrát širší nežli ulice Warmoes v Amsterdamu" [Ruiters in Thompson 1990: 80]. V témže roce holandský obchodník Samuel Blommaert² (1583-1651) s obdivem prohlásil, že královský palác je stejně rozsáhlý jako město Harlem [Jones 1995]. Podobné pocity při návštěvě Beninu zažil také německý obchodník Joshua Utzheimer, který porovnával v roce 1803 zdejší palácový komplex co do velikosti s německým městem Tübingen [Walker 2006].

První mapu města společně s popisem jeho architektury a urbanistického prostoru vytvořil v roce 1668 holandský geograf Olfert Dapper (1635-1689). Ten sice Benin nikdy osobně nenavštívil, ale měl k dispozici poměrně rozsáhlé, autentické a přesné informace a popisu města od lidí, kteří zde skutečně pobývali. Podle Dappera město Benin tvořilo třicet přímých, širokých a nedlážděných ulic, podél kterých byla vystavěna prostorná hliněná obydlí, jejichž střechu pokrývaly palmové nebo banánové listy. Beninské domy nejsou vyšší nežli dva metry, uvnitř ale zpravidla mají dlouhé široké chodby, zejména pokud se jedná o domy náležející nobilitě. Interiér domů tvoří několik místností, které jsou odděleny bytelně postavenými stěnami z červené hlíny. „Stěny místností dokážou jejich obyvatelé udržovat velmi lesklé a hladké jako zrcadla prostřednictvím omývání a drhnutí, podobně jako je to prováděno $\mathrm{v}$ Holandsku prostřednictvím křídy. Horní patra jsou zbudována ze stejného druhu hlíny; každý dům je navíc vybaven studnou, aby mohl být zásobován vlastní čerstvou vodou" [Roth 1968: 160]. Významným zdrojem informací o Beninu byl holandský obchodník David van Nyendael (1667-1702), jenž toto město navštívil v letech 1699 a 1702 [Roth 1968; Payne 2011]. Ten ve svém popisu registroval, jak růst městské populace ovlivňuje růst městské zástavby. Podle jeho názoru byl v době jeho návštěvy Benin „velice hustě zastavěný a svým způsobem přelidněný" [Nyendael in Talbot 1926: 167]. Zprávu o osobité a současně

\footnotetext{
Svoji architektonickou koncepcí vladařův palác připomínal antický římský dům s atriem.

2 Blommaert, který žil na území Afriky několik let, byl jedním z hlavních informačních zdrojů Olfera Dappera [Connah 1975].
} 
funkční koncepci ulic města zanechal také francouzský kapitán Jean Francois Landolphe (1747-1825), který obchodoval v povodí řeky Formosa v letech 1769 až 1792 [Omoerha 1975]. „Ulice jsou velice široké; $v$ jejich středu je trávník, na kterém se pasou kůzlata a ovce; zhruba třicet stop od domů je vodorovná silnice pokrytá pískem, aby po ní mohli kráčet místní obyvatelé“ [Landolphe in Roth 1903: 163]. Na sklonku 19. století již ale město Benin ani jeho architektura nebo urbanistické řešení žádný úžas Evropanů nevyvolávaly. Tento postoj je pochopitelný, nebot průmyslová města ve vyspělých zemích Evropy byla s tradičními africkými městy nesrovnatelná. Britský vicekonzul Oil Rivers Protectorate Henry Lionel Gallwey (1859-1949) tak pejorativně a bez jakéhokoliv obdivu popisuje město Benin jako „roztroušenou kolekci domů, postavenou tu a tam ve shluku, v menším nebo žádném řádu“ [Gallwey 1893: 130]. Podobně britský důstojník Reginald Bacon, v době kdy vstoupil s invazní armádou do hlavního města beninského království, popisuje tento urbanistický komplex jako „město tvořené nepravidelnou zástavbou, jíž tvoří skupiny domů, které jsou odděleny nepravidelnými pruhy křovisek“" [Bacon 1897: 86].

Historicky původní a architektonicky autentickou podobu města Benin z doby jeho největší slávy si lze dnes jen velice těžko představit. $O$ to důležitější bylo realizovat ve městě Benin systematický archeologický výzkum. Tohoto úkolu se ujal v letech 1961 až 1964 britský archeolog Graham Connah, který se pokusil pomocí systematických výkopových prací nalézt artefakty poskytující nové informace o historii tohoto města. Connah zkoumal historický vývoj Beninu od 13. století. Zvláštní pozornost přitom věnoval zachovaným pozůstatkům opevnění města, jehož počátky na základě radiokarbonového datování kladl do doby kolem roku $1340 \pm 150$ [Connah 1975]. Je zajímavé, že beninský historik Jacob Egharevba, který ke stanovení stáří hradeb použil orální tradici, dospěl k obdobnému závěru, totiž že opevnění města vzniklo kolem roku 1460 [Egharevba 1968]. Shoda radiokarbonového datování a datování vyvozeném na základě orální tradice naznačuje, že komplexní fortifikační systém skutečně vznikl v polovině 15. století [Connah 1975]. Connah, který zmapoval 145 kilometrů rozsáhlou sít opevnění, nabyl přesvědčení, že se jednalo o „proces pomalého splynutí rozptýlených vesnic, které byly oddané hlavní autoritě, až oba Ewuare v 15. století vybudoval pravý urbánní celek s formální městkou obranou“ [Connah 1972: 33]. Na Connahovy výzkumy navázal v sedmdesátých letech 20. století britský archeolog Patrick Darling. Ten zjistil, že Connahem popsané opevnění tvořilo pouze malou část mnohem rozsáhlejšího obranného systému, který kromě města chránil také přilehlé vesnické osady a kmenová teritoria. Komplexní beninský fortifikační systém z tohoto hlediska pokrýval $6500 \mathrm{~km}^{2}$ a dosahoval úctyhodné délky asi 16000 kilometrů [Darling 1976, 1998]. Nové archeologické výzkumy pozůstatků historického města Benin a teritorií, jež byla pod ochranou jeho opevnění, však znemožňuje rychlý růst moderní městské aglomerace i nedostatek finančních prostředků. Mnoho poznatků o dávném Beninu tak zůstává pohřbeno nejen pod vrstvou hlíny, ale také pod novými stavbami a expandující civilizační infrastrukturou. Stávající archeologické nálezy ale přesto prokázaly, jak významným centrem kulturních kontaktů bylo královské město Benin v dobách své největší slávy.

\section{Království Benin v síti evropských obchodních a mocenských zájmů}

Beninské království bylo před příchodem prvních Evropanů do západní Afriky předním ohniskem svébytné a autonomní africké kultury. Mezi první Evropany, kteří se dostali 
do kontaktu s beninským královstvím, patřil portugalský mořeplavec Ruy de Sequeira (1430-1482). Ten na území beninského království údajně vstoupil v roce 1472. Neexistují ale žádné důkazy o tom, že navštívil hlavní město království [Asante 2012]. Prokazatelně první Evropané poctili svojí návštěvou beninský královský dvưr v roce 1484. Mužem, který zahájil období kulturních a obchodních kontaktů mezi Západem a beninskou ř́íśí, byl portugalský diplomat João Afonso d’Aveiro, známý jako Afonso de Paiva (kolem 1460-1490). Je př́značné, že již v průběhu tohoto setkání Binijci pochopili, jak užitečné by bylo získat přístup k evropským zbraním a surovinám. Oproti tomu si Afonso de Paiva si uvědomoval, jak užitečné mohou být pro portugalský královský dvůr obchodní kontakty s beninskou rríší. Proto v roce 1486, při svém návratu do Portugalska, s sebou přivedl poselstvo z Beninu jako prríslib budoucí spolupráce mezi oběma zeměmi [Curley 2012].

Akulturační kontakty mezi Portugalci a Binijci se originálním způsobem promítly do beninského umění. Portugalci, vnímaní domorodci jako symbol obchodního úspěchu a vojenské moci, inspirovali beninské řemeslníky natolik, že z nich učinili významný motiv svých výtvarných děl. Beninští umělci tímto způsobem na principu analogie artefakty ozvláštňovali sílu a moc vládců Beninu. Obrazy Portugalců na maskách, zvonech, slonovinových klech, bronzových deskách a skulpturách zdůrazňovaly výjimečný status beninského vladaře. Skutečnost, že se Portugalci stali jedním z důležitých motivů beninského umění, lze interpretovat jako doklad toho, že se Evropané stali součástí beninského světa. Za rozhodující mezníky vzájemných kontaktů Evropanů a Binijců lze označit rok 1484 , kdy na beninskou půdu vstoupil Afonso de Paiva, a poté rok 1515, v němž navštívil beninskou ř́ísi portugalský posel Duarte Pires [Newitt 2010].

Binijci považovali Portugalce za posly přicházející z podmořské říše boha moří, bohatství a plodnosti Olokuna. Moře bylo tradičně v beninské mytologii spojováno s bohatstvím a status pozemského vládce Beninu analogicky odpovídal mocenské pozici, jíž zaujímal v podmořské říši její vládce, moudrý, přísný a trpělivý bůh Olokun. Proto byl beninský oba považován za pozemského Olokuna. Jejich postavy jsou dokonce v beninském umění zaměnitelné. Lidská figura s končetinami profilovanými do ploutví žraloka skvrnitého představuje beninského vladaře v božském vzezření. Ztvárnění vody evokuje bohatství krále, zatímco končetiny vyjadřují prahovou schopnost vstupovat z jednoho království do druhého [Ryder 1969; Ben-Amos 1995; Newitt 2005; Curnow 2007]. Skutečnost, že součástí beninské mytologie je bůh moře, svědčí o tom, že Binijci měli povědomí o existenci Atlantického oceánu již ve velmi dávných dobách. Přesně stanovit dobu, kdy se Binijci s mořem reálně setkali, je velmi problematické. Je ale pravděpodobné, že první zprávy o existenci moře zprostředkovali místní domorodí obchodníci. V sedmdesátých letech 15 . století ale začali z moře do delty Nigeru vplouvat na svých lodích Portugalci, kteří byli ztotožněni s posly vládce podmořské ř́še. Zprávy o příchodu Portugalců se rychle šírily. Řada indicií naznačuje, že beninský oba Olua, který vládl v letech 1473-1480, si byl dobře vědomý, že „lidé přicházející z moře“ pronikají deltou řek do nitra západní Afriky [Ekeh 2007].

První kontakty Evropanů s domorodými obyvateli západní Afriky, k nimž došlo již v polovině 15. století, byly agresivní a krvavé. Počáteční brutální násilné útoky Portugalců na pobřežní západoafrické kmeny ale postupně vystřídalo období, v němž převládla snaha Západu po nastolení principů, umožňujících pravidelně, klidně a bezpečně vzájemně obchodovat. Předmětem zájmu Evropanů bylo zejména zlato, koření a slonovina, za které výměnou do Afriky putovalo kovové zboží a textilie. Svůj podíl na růstu objemu 
námořního obchodu měly technologické inovace ve stavbě evropských lodí, pokrok v navigaci a rozkvět námořní kartografie. Na základě toho Portugalci a poté v 16. a 17. století také Holand’ané, Francouzi a Angličané námořním obchodem úspěšně konkurovali tradičním africkým vnitrozemským obchodním stezkám. Portugalci od počátku prvních kontaktů v západní Africe doufali, že v Beninu naleznou pevného spojence a obchodního partnera, který jim umožní snížit konkurenceschopnost muslimských obchodníků v severní Africe. Proto usilovali ovlivnit osudy beninského království jak svými obchodními a diplomatickými aktivitami, tak šířením křest’anské víry.

Stinnou stránku evropských obchodních aktivit v dějinách Afriky představuje atlantický obchod s černými otroky. Je třeba přiznat, že otroctví existovalo v beninském království stejně jako v mnoha dalších afrických zemích, dlouho před příchodem Evropanů. Vlastnictví velkého množství otroků bylo znakem sociálního statusu a vysoké prestiže svobodného muže nebo hodnostáře. Zotročení lidé byli v beninském království využíváni jako služebníci vladaře a hodnostářů, pracovní síla při obdělávání zemědělské půdy a v řemeslné výrobě. Otroci nacházeli uplatnění také při vedení vojenských operací. Mohli se stát i předmětem obchodních transakcí nebo být využiti jako lidské oběti. Beninský oba používal své otroky k zajištění efektivního fungování cechovního systému a při zakládání nových vesnic, jejichž úkolem bylo zvyšovat zemědělskou produkci. Tradiční patriarchální otrokářství, které má na africkém kontinentě dlouhou tradici, se ale kvalitativně lišilo od obchodu s otroky, který zavedli evropští kolonizátoři. „Vzrůst obchodu s otroky proměnil patriarchální otrokářství v divokou štvanici na lidskou kořist. Silnější prodával slabšího, rodinné svazky přestaly existovat, nebở rodiče prodávali své děti nebo děti své rodiče jako nějaké zbytečné předměty. Portugalci vypalovali otrokům cejch, jako by to byly ovce“ [Davidson 1962: 143].

Důsledky evropského obchodu s otroky byly pro africké země doslova zničující. Vývoz otroků ze západní Afriky po čtyřri staletí snižoval demografický přírůstek domorodé populace. Množství otroků, jež odcházelo z oblasti zálivu Benin v letech 1650 až 1850, je odhadováno na 2 miliony lidí [Lovejoy 2004]. Obchod s otroky destruoval původní africké instituce, dezintegroval sociální strukturu a organizaci místních kmenů, vedl k růstu bídy a utrpení domorodců a stimuloval růst zlovůle, nespravedlnosti a nelidskosti Evropanů. Negativním důsledkem obchodu s otroky, kteří za nelidských podmínek v podpalubí otrokářských lodí putovali do Ameriky, byl také mravní rozklad základních lidských hodnot. „Honička na otroky se proměnila v hromadné štvanice, při kterých padaly mravní zábrany, a hynul cit pro lidskou důstojnost. Těžko odhadneme škody, které otroctví ve velkém napáchalo ve společnostech a státech, které byly touto kletbou postiženy“ [Davidson 1962: 143]. Obchod s otroky se podílel nejenom na zpomalení ekonomického a demografického růstu západoafrických zemí, ale také výrazně přispíval k diverzifikaci a decentralizaci místních společenství a komunit.

$\mathrm{V}$ rané fázi obchodu s africkými otroky se Portugalci zaměřili na Benin, který díky svým častým vojenským výbojům disponoval značným množstvím zajatců, z nichž bylo možné učinit předmět prodeje. Po roce 1516 ale beninský oba vydal zákaz vývozu mužských otroků (na ženy se zákaz nevztahoval), ze svého království, nebot’ se oprávněně obával nedostatku pracovních sil. Portugalští otrokáři proto uzavřeli obchodní spojenectví s královstvím Kongo, jehož král Alfonso I. zvaný Mbemba Nzinga (kolem 1460-1542) ve 20. letech 16. století vyvážel každoročně dva až tři tisíce otroků. Toto drancování lidských 
zdrojů ale Kongo brzy vyčerpalo, a tak Portugalci v roce 1576 zrrídili nové centrum obchodu s otroky v Luandě [Falola 2002]. V 16. století ještě nebyl obchod s otroky př́liš rozsáhlý, ale v souvislosti s narůstající potřebou pracovních sil na karibských a amerických třtinových plantážích se vývoz afrických otroků v 17. století neustále zvyšoval. Během tohoto století bylo ročně v průměru prodáno 20 tisíc otroků. V 17. století se do obchodu s otroky opět zapojil Benin, nebot jeho vladaři do značné míry ztratili královský monopol nad obchodem s Evropou, čehož beninští hodnostáři využili a zákaz vývozu otroků z roku 1516 začali ignorovat. Vývoz afrických otroků do Ameriky dosáhl svého vrcholu v průběhu 18. století. Od konce 18. století ale narůstala ze strany vyspělých průmyslových zemí snaha o zrušení otroctví. Hlavním důvodem byl rozvoj kapitalistického výrobního způsobu a hledání nových cest $\mathrm{k}$ průmyslovému ekonomickému růstu. $\mathrm{V}$ podmínkách kapitalismu totiž nebyla práce otroků dostatečně efektivní a ekonomicky výnosná, nebot’ hybnou silou průmyslové výroby se stala sice svobodná, ale levná pracovní síla. Atlantický obchod s otroky přesto přetrvával ještě v 19. století, i když jeho objem zvolna klesal. Philip D. Curtin [Curtin 1969] na základě studia dokumentů o otrocích vyloděných v Americe a demografických údajů v amerických koloniích dospěl k závěru, že v období od roku 1451 do roku 1870 bylo do Ameriky dopraveno 9391100 otroků.

Kromě otroků dováželi Portugalci z beninského království kamenné korále (kori), africké červené dřevo, bavlněné textilie a slonovinu. Důležitou obchodní komoditou byl také beninský pepř, který byl až do roku 1506 nejvíce importovaným zbožím. Svoji roli přitom sehrála skutečnost, že v letech 1486 až 1487 Portugalci založili faktorie na pepř v obchodním středisku Ughoton. Svým objemem ale africký obchod s beninským pepřem nebyl schopen na začátku 16. století konkurovat dovozu pepře z Indie. To ve svých důsledcích vedlo $\mathrm{k}$ uzavření portugalských obchodních středisek v Ughotonu. K poklesu obchodních aktivit přispělo Evropanům nepříznivé místní klima, které přispívalo k šíření tropických nemocí. Tato skutečnost ale nijak neoslabila zájem Evropanů o beninské suroviny a další místní zdroje. Pepř, bavlněné textilie a slonovina byly důležitými komoditami také po zahájení obchodních kontaktů s Angličany (přibližně od roku 1550) a s Nizozemci (přibližně od roku 1600). Benin jako obchodní partner Portugalců, později i Holand’anů a Angličanů, se stal také zdrojem palmového oleje, jaspisu, leopardí kủže, pryskyřice a sekvojí [Ryder 1969; Euba 1981; Birmingham 2010].

Monopol na zahraniční obchod měl v beninské říši ve svých rukou beninský oba. Ten reguloval import a export zboží otevřením nebo uzavřením trhu podle toho, jak výhodná pro něj byla cenová nabídka komodit, s nimiž bylo obchodováno. Jako měna pro obchod Beninu se Západem sloužily mušličky kauri z Malediv a manila (bronzové, měděné a mosazné nákotníky). Manila byla ve velkém množství do Beninu importována Portugalci a zde směňována především za otroky. V letech 1505 až 1507 bylo v portugalském obchodním středisku v Ughotonu využito pro obchodní transakce přibližně 13000 kusů manil. Velká část tohoto kovového materiálu byla domorodými řemeslníky roztavena a použita k výrobě uměleckých artefaktů, jež byly exportovány zpět do Evropy nebo se staly součástí interiéru královského paláce v Beninu [Sundström 1974]. Ve srovnání s tradičními beninskými surovinami, jako hlína a dřevo, oceňovali afričtí domorodci vysoce trvanlivost artefaktů zhotovených z mědi a kovových slitin. Tyto materiály byly považovány za nadčasové, nebot v očích Binijců nepodléhaly přirozenému rozkladu a překračovaly svojí trvalostí horizont lidského života. Přístup k manile jako cizímu importovanému materiálu podléhal 
ze strany beninské elity kontrole. Na konci 15. století si domorodci ve střední Africe vysoce cenili čistou měd’ V beninském království na počátku 16. století ale preference mědi jako výchozího materiálu pro výrobu kovových artefaktů poklesla. Bylo to způsobeno tím, že při výrobě uměleckých artefaktů technikou ztraceného vosku je použití čisté mědi mnohem náročnější nežli takových slitin, jako je bronz nebo mosaz. Kromě kovů Evropané do Beninu přiváželi damašek, hedvábí, mušličky kauri, klobouky nebo korále ze Středomoří. Později se staly předmětem zájmu také zbraně, střelivo, alkohol, tabák nebo olovo. Velké oblibě se v Beninu těšily indické tkaniny, které byly využívány například při výrobě obřadních kostýmů [Feinberg 1989].

V 15. a 16. století byla součástí kulturních kontaktů Binijců s Evropany činnost portugalských misionářů. Portugalští dominikánští kněží zahájili své náboženské aktivity na území Beninu na žádost beninského vládce Esigie v srpnu 1515. Misionáři se v Beninu dále usazovali v migračních vlnách, konkrétně v letech 1651 až 1653, 1664 až 1674, 1695 a 1713 až 1714 [Kilger 1932]. Ačkoliv v Beninu probíhala evangelizace, konverze, křest a výstavba kostelů, z dlouhodobé perspektivy považovali Portugalci výsledky svých křestanských misií za nepř́liš uspokojivé. Je pravděpodobné, že ochota beninských vladařů tolerovat portugalské misionáře souvisela s papežským dekretem, který zakazoval, aby střelné zbraně vlastnili nekřestané. Vládci Beninu si byli vědomi toho, že pokud nastane v jejich zemi u části obyvatelstva konverze ke křestanství, budou jim poskytnuty evropské střelné zbraně, které jim poskytnou převahu v jejich lokálních válkách. Tento utilitární postoj samozřejmě nevedl beninské vládce $\mathrm{k}$ dlouhodobé a stálé podpoře šíření křestanství v jejich zemi. Úspěchy křestanských misí v Beninu se tak podobaly planoucí a hasnoucí svíci, jejíž plamen ovlivňovala celá řada faktorů včetně osobnosti a mocenských aspirací konkrétního vládce Beninu, vojenské a politické situace v zemi a míry mortality misionářů způsobené tropickými nemocemi. Kulturní kontakty na úrovni šíření evropských idejí se promítly i do beninského vzdělávacího systému. V roce 1529 byla založena škola ve městě Elmina, jejímž cílem bylo nejen uvést domorodce do znalosti Bible, ale také naučit je číst a psát. Je také známo, že řada mladých mužů z beninské elity si osvojila základy portugalštiny, kterou úspěšně využívali při jednání s Evropany [Oriaifo - Gbenedio 1992].

Kulturní kontakty na úrovni difuze materiální kultury souvisely zejména s obchodními aktivitami. Bylo to dáno tím, že království Benin po řadu století představovalo důležitou křižovatku východozápadních a severojižních obchodních cest v západní Africe. Kontakt s Evropany byl ale pouze jedním z elementů širšího komplexu ekonomických, sociálních a politických vztahů, které v této oblasti tradičně existovaly mezi různými královstvími, městskými státy, přístavy a mezinárodními obchodními cestami. Beninské artefakty stejně jako beninský pepř představovaly významnou složku regionálního obchodu a velké lákadlo pro evropské obchodníky [Birmingham 2010].

Na sklonku 16. a v průběhu 17. století získali v západní Africe vedoucí pozici evropské obchodní moci Holand’ané. Ti město Benin ve svých zprávách popisují jako vzkvétající a rozsáhlé královské sídlo, jež je v řadě parametrů srovnatelné s evropskými metropolemi. Holandané si uvědomovali, že Benin představuje strategickou obchodní křižovatku, po níž může z nitra západní Afriky proudit směrem k západnímu pobřeží cenné zboží a suroviny. O rozsahu obchodních transakcí mezi Binijci a Holand’any svědčí dochovaná zpráva, podle níž lod’ Beninreyse v roce 1663 přepravila do holandského prrístavu a správního centra Nassau na pobřeží Guinejského zálivu obchodní zásilku, čítající 6461 kusů beninských 
textilií. Podle dalších historických pramenů Holandané zakoupili v Ughotonu, v letech 1644 až 1646, více než 16000 kusů modrých nebo modrobílých beninských textilií. Ty dále směřovaly do Costa da Mina (záliv Benin), kde byly směňovány za zlato, a jižně do Gabonu a Angoly, kde byly směňovány za otroky a slonovinu. Významným artiklem, který na konci 17. století vedl k růstu objemu obchodu s Binijci, se stala slonovina, jejíž prodej zaručoval vysoký zisk jak Evropanům, tak Afričanům [Kriger 2006; Gore 2007].

V roce 1807 vstoupil ve Velké Británii v platnost zákon zakazující obchod s otroky. To způsobilo pokles obchodu jak se slonovinou, tak s beninskými textiliemi [Law 2002; Lovejoy 2004]. Současně od sedmdesátých let 18. století a po celé 19. století neustále vzrůstala poptávka Evropanů po beninském palmovém oleji. Narůstal i význam kaučuku, který představoval významnou surovinu pro britský textilní průmysl a později také pro výrobce pneumatik. Stále silnějším obchodním partnerem na beninském trhu se v tomto období začali stávat Britové, kteří ve čtyřicátých letech 19. století v deltě řeky Niger založili několik obchodních středisek zaměřených na export palmového oleje. V polovině 19. století již měli Britové společně s Francouzi hlavní komodity mezinárodního obchodu s Beninem pod svojí kontrolou. Importovali sem zejména střelné zbraně, zrcadla, klobouky, textilie, tabák, alkohol nebo kauri výměnou za slonovinu, barviva, textilie, dřevo, kaučuk a palmový olej. Ve 2. polovině 19. století začal Benin ztrácet vojenskou sílu i politickou a ekonomickou autoritu. Na severu čelil vojenské hrozbě nájezdů kmenů, jako byli Fulbové a Nupeové, na západě narůstal tlak ze strany západních mocností snažících se prosadit na území beninského království volný obchod. Portugalci a Holand’ané v rámci svých kontaktů s Beninem i nadále primárně sledovali své obchodní a ekonomické zájmy. Nový postoj k beninskému království ale zaujala Velká Británie, která ve druhé polovině 19. století začala stále více usilovat o plnou vojenskou, politickou a ekonomickou kontrolu tohoto teritoria.

\section{Diplomatické preludium britské koloniální expanze}

V 19. století království Benin procházelo složitým obdobím sporů o následnictví, které způsobily vnitřní politickou a sociální nestabilitu království a občanské války. Zejména poslední desetiletí 19. století bylo dobou oslabení mocenské autority Beninu a jeho vojenské a politické kontroly nad ovládaným územím, jehož rozsah se zmenšoval. Osud beninského království stále více ovlivňovaly také externí faktory související s koloniální expanzí Západu ve střední Africe.

Ve druhé polovině 19. století navštívil beninské království britský diplomat a orientalista Richard Francis Burton (1821-1890), který působil jako konzul na ostrově Fernando Pó (dnes Bioko) při západním pobřeží střední Afriky. Jeho návštěva Beninu v roce 1862 přispěla $\mathrm{k}$ vytvoření negativního obrazu tohoto království v očích Evropanů. Burton ve svých zápiscích doslova uvedl: „ke cti Beninu nelze přiznat nic; toto místo čpí krví a vznáší se nad ním stín smrti“ [Burton 1863: 286]. Podle Burtona lemovaly cesty směřující k paláci pozůstatky lidských obětí. Možná z tohoto důvodu Burton označil Binijce za dábly [Lovell 1998]. Cílem jeho mise ale nebylo poznávat exotickou africkou zemi, nýbrž prosazovat britské ekonomické a obchodní zájmy. Burton chtěl především přesvědčit beninského vládce k zavedení volného obchodu. V tomto období se pokoušeli zefektivnit své obchodní aktivity na území beninské království také další evropští obchodníci. Ti požadovali zejména zrušení poplatku obchodníkům, kteří nemají binijský původ. 
Zásadní změnu ve vztahu Západu a Beninu znamenala Berlínská konference, jež proběhla $\mathrm{z}$ iniciativy německého kancléře Otto von Bismarcka na přelomu let 1884 a 1885 . Mezi nejvýznamnější závěry konference patřilo, kromě podpory svobody obchodu v západoafrickém teritoriu, formulování politiky, podle níž „evropské nároky na africká území musí být nadále podloženy podstatněji než pouhým neformálním vlivem, jaký si doposud osobovala prostřednictvím své námořní a obchodní síly Velká Británie“ [Iliffe 2001: 130]. $\mathrm{V}$ průběhu konference bylo také rozhodnuto, že dolní Niger a Benin patří do sféry vlivu Velké Británie, která tak získala legitimní důvody k dalším diplomatickým vyjednáváním s beninským obou. Berlínská konference také umožnila, aby v roce 1885 vznikl britský protektorát nad deltou Nigeru Niger Districts Protectorate. Ten v roce 1891 změnil své označení na Oil Rivers Protectorate a následovně roku 1894 na Niger Coast Protectorate. Pro tuto oblast byly založeny také vojenské jednotky Oil River Irregulars, přejmenované v roce 1891 na Niger Coast Constabulary se sídlem velitelství v Calabaru. V roce 1896 byla ustanovena obchodní společnost Royal Niger Company, jež si zřídila vlastní policejní jednotku Royal Niger Company’s Constabulary, k níž patřili Hausové, Jorubové a Nupeové. Cílem protektorátu byla nejenom kontrola nad již ovládanými územím a jeho zdroji, ale také další teritoriální koloniální expanze Velké Británie [Porter 1994; Lynn 1998].

Beninské království bylo již od 16. století vyhledávaným cílem obchodníků, které lákaly místní surovinové zdroje, k nimž patřily zejména palmový olej, kaučuk a slonovina. Nezávislé beninské království ale na svém území velmi př́sně kontrolovala pravidla obchodu a chránila ekonomické zájmy beninského vládce. Beninský oba neměl zájem měnit svoji nezávislou obchodní politiku jak ve vztahu k evropským, tak k africkým obchodníkům, jakými byli např́ílad sousedé Binijců obývající území delty řeky Niger. Beninští vládci po několik staletí úspěšně čelili vnějším tlakům ze strany evropských koloniálních mocností i afrických znepřátelených kmenů. Na sklonku 19. století již ale bylo zřejmé, že Velká Británie využije všech dostupných prostředků, aby se Benin stal součástí jejího koloniálního impéria v západní Africe.

Diplomatický tlak Velké Británie na beninské království vyvrcholil v březnu roku 1892, kdy Benin oficiálně navštívil britský vicekonzul Oil Rivers Protectorate Henry Lionel Gallwey (1859-1949). Jeho záměrem bylo připojit Benin k protektorátu a vytvořit $\mathrm{z}$ něj legitimní britskou kolonii. Gallwey vytvořil propracovaný plán, jehož součástí byl na jedné straně průzkum oblasti řeky Benue, na straně druhé diplomatické kroky. Ty spočívaly ve vyslání poslů, kteří měli tehdejšího obu Ovonramwena a jeho hodnostáře ujistit o mírových úmyslech Velké Británie, a zajistit, aby byl Gallwey osobně přijat beninským vladařem [Ryder 1969]. Na setkání s beninským obou Ovonramwenem byl Gallwey údajně nucen čekat tři dny. Oba byl skeptický k motivům a cílům Gallweyho mise, ale připouštěl možnost, že bude uzavřena vzájemně výhodná smlouvy o přátelství a obchodu [Gallwey 1930; Igbafe 1970]. Bohužel právě tato smlouva vedla k omezení beninského vládce a předznamenala začátek pádu beninského království. Její přijetí totiž ve svých důsledcích znamenalo, že Benin bude nucen akceptovat britskou hegemonii i právo Evropanů obchodovat kdekoliv na území království [Falola 2009]. Tím beninský oba ztratil do té doby nikým neomezený monopol nad všemi obchodními artikly. Když však oba Ovonramwen zjistil, že dokument je klamnou lstí umožňující učinit z království Benin kolonii Velké Británie, ustoupil od plnění smlouvy a vydal vyhlášku omezující vstup britských úředníků a obchodníků na území Beninu. 
Nad tím, za jakých okolností byla smlouva mezi beninským vladařem a Gallweyem skutečně uzavřena, se dodnes vznáší mnoho otazníků. Předmětem diskuse a polemik je zejména Gallwayho tvrzení, že beninský oba souhlasil se všemi podmínkami smlouvy, a to v plném rozsahu. Legitimitu smlouvy zpochybňují také historické okolnosti a kulturní kontext, za nichž byla údajně smlouva podepsána. Existuje dokonce hypotéza, podle níž osobní setkání Gallweye s vladařem vůbec neproběhlo. V době, kdy Gallwey navštívil Benin, totiž nemohl být obou přijat, nebở se právě konala důležitá tradiční slavnost igue, která jednání beninského vládce s cizinci znemožňovala. Podle jiné interpretace Gallweye přijali nejdřive hodnostáři; ti se ale zdráhali zprostředkovat jeho setkání s obou. Gallwey si ale údajně schůzku s beninským vládcem vynutil pohrůžkou, že pokud odejde s nepořízenou, prŕíště se již nevrátí jako přítel. Toho se hodnostáři zalekli a setkání s obou Ovonramwenem zajistili.

Podle nejrozšířenější verze měla schůzka beninského vládce s britským diplomatem následující průběh. Oba Ovonramwen přivítal Gallweye v doprovodu hodnostářů a dvořanů, s nimiž průběžně body smlouvy konzultoval. Protože byl ujištěn, že se nejedná o válečné jednání, s podepsáním smlouvy zpočátku souhlasil. Svůj postoj ale změnil a nakonec odmítl smlouvu nejen podepsat, ale dotknout se i pera, jímž měla být ujednání stvrzena. Někteří hodnostáři se však pera dotkli, čímž symbolicky vyjádřili svưj souhlas s jejím obsahem a plněním. Gallwey později tvrdil, že oba a jeho hodnostáři souhlasili se smlouvou v jejím v plném rozsahu. Přitom její součástí byly pro beninskou ř́ši značně nevýhodná ustanovení. Smlouva například obsahovala tezi, podle níž „teritorium řeky Benin a země Jekeri jsou vyhrazeny pro její výsost“ [Salubi 2005: 89]. Dále také požadavek, aby beninští hodnostáři byli nápomocni britskému konzulátu při výkonu povinností, jako jsou „komerční zájem (...) a obecný pokrok civilizace“ [tamtéž: 90]. Paradoxní je, že z perspektivy beninského vladaře a tradic jeho kultury neměla smlouva zákonnou moc. Oba se domníval, že z ní pro něj neplynou žádné legislativní závazky nebo vojenské dopady [Falola 2009]. V této souvislosti nelze ani vyloučit, že beninský oba nechápal, že se jeho země v té době stala součástí širší koloniální politiky, bude vystavena bezohledným potřebám kapitalistického trhu a hrozí ji drancování jak místních surovin, tak domorodých lidských zdrojů. Na druhé straně je možné, že si beninský vládce velice dobře uvědomoval hrozící vojenské nebezpečí ze strany imperiální mocnosti, proti níž jeho armáda v té době nebyla schopná uspět. Sílící hrozbu intervence ze strany Velké Británie navíc potvrzovala skutečnost, že Britové stále více posilovali své vojenské pozice na západním africkém pobřeží.

V letech 1892 až 1896 narůstal na beninského vládce a jeho administrativu tlak ze strany evropských úředníků a obchodníků, kteří žádali, aby skutečně naplnil obsah smlouvy a respektoval její ekonomické a obchodní důsledky. Britský komisař Niger Coast Protectorate Claude Maxwell MacDonald (1852-1915) považoval smlouvu za zcela legitimní, a proto její ignorování ze strany Beninu chápal jako její porušení a projev nepřátelského chování. MacDonaldovu nespokojenost s postoji Binijců $\mathrm{k}$ britské snaze ekonomicky pacifikovat beninské království a nastolit zde nové pořádky, ilustrují jeho vlastní slova: „(...) ale původní obyvatelé mají velký odpor k tomu, aby začali zpracovávat novou komoditu. Mají velice konzervativní myšlení a raději kráčí ve stopách svých předků..." [MacDonald 1893]. Claude MacDonald, který Niger Coast Protectorate považoval za nástupiště umožňující další šíření britského vlivu v přilehlých vnitrozemských afrických oblastech, inovoval a posílil úřední řídící institucionální strukturu 
protektorátu. V období od září roku 1895 a poloviny roku 1896 lze zaznamenat celkem tři pokusy reprezentantů protektorátu uvést do praxe smlouvu, kterou Britové s beninským vladařem uzavřeli. První pokus uskutečnil vicekonzul jmenovaný pro Benin District Peter Wade Grant Copland-Crawford (1856-1897). Následoval druhý pokus, který inicioval konzulární zprostředkovatel Ralph F. Locke, a poté pokus třetí, jenž učinil důstojník Niger Coast Protectorate kapitán Arthur Maling (1870-1897). Všechny snahy dosáhnout zásadního plnění obsahu smlouvy avšak byly neúspěšné. To negativně pocitovali zejména obchodníci, kteří chtěli prosadit nová pravidla pro obchod s beninskými surovinami. Ke konečnému pádu Beninu tak významným způsobem přispěly britské ekonomické a obchodní zájmy, zejména snaha Evropanů získat kontrolu nad zdroji místního kaučuku a změnit pro ně nevýhodné stávající podmínky obchodování [Igbafe 1970].

Beninské království po celou dobu své existence aktivně obchodovalo se Západem. Na základě své politické nezávislosti si ale Binijci pro obchod s cizinci sami určovali pravidla, jež v řadě případů Evropanům nevyhovovala. Rozhodovali např́íklad o tom, kteří obchodníci mohou na jejich území působit, př́ísně kontrolovali přímořský obchod ve vztahu k cizincům, vyžadovali poplatky od obchodních lodí a zvýhodňovali obchodní transakce beninského vladaře a jeho hodnostárù. Beninský oba hrál v obchodních aktivitách významnou roli např́iklad tím, že monopolizoval export palmového oleje, který až do pádu Beninu představoval jednu z mála surovin, jejichž vývoz byl ze země oficiálně povolen. Ve 40. letech 19. století se významným obchodním artiklem stala také podzemnice olejná. Krátce poté se v 70. letech zvýšila poptávka po jádrech palmy olejné a ze strany evropských obchodníků narůstal zájem o dodávky přírodního kaučuku [Hargreaves 1974]. Součástí britské imperiální strategie ve vztahu k Beninu proto byla snaha dosáhnout kontroly nad místními zdroji surovin a aktivně ovlivňovat zdejší obchodní transakce. Prosazení volného obchodu na území beninského království by navíc otevřelo prostor pro rozvíjení dalších ekonomických aktivit nezávisle na souhlasu beninského vládce a místní aristokracie [Igbafe 1980]. Tradiční systém beninské státní moci totiž primárně podporoval ekonomické zájmy vládce oba a vládnoucí oligarchie, umožňoval kontrolu obchodu, reguloval šíření zbraní a dostupnosti střelného prachu. Pokud by se Velké Británii podařilo v souladu s uzavřenou smlouvou prosadit na území Beninu svobodný obchod, otevřely by před evropskými kolonizátory nové možnosti další ekonomické expanze.

\section{Britská vojenská invaze a dobytí beninského království}

V roce 1896 podal jeden obchodník k liverpoolské obchodní komoře stížnost, že beninský oba nedovoluje svému lidu obchodovat s kaučukem a odmítá jakékoliv pokusy otevř́t beninský trh svobodnému obchodnímu podnikání. Na neochotu beninského vládce dodržovat usnesení smlouvy z roku 1892 reagoval vrchní konzul James Robert Phillips, který byl v ř́inu roku 1896 jmenován vrchním konzulem a osobně navštívil oblast řeky Beninu. Jedním z jeho prvních kroků, jimiž se pokusil podpořit britské ekonomické zájmy, bylo, že začal doporučovat místním hodnostářum, aby neodváděli tribut beninskému obovi. Již měsíc po svém uvedení do funkce Phillips odeslal telegram, ve kterém uvádí, že beninský vladař „cíleně přerušil veškeré obchodní aktivity a fakticky tak v této části protektorátu zastavil cestu pokroku“ [Newbury 1971: 147]. Tím podle Phillipse utrpěla zejména 
ekonomická prosperita loajálních britských spojenců, jimiž byli příslušníci etnické skupiny označovaní jako Jakri nebo také Itsekiri. Jednalo se o domorodé rybáře a obchodníky, jejichž území sousedilo s beninským královstvím. Výhodná geografická pozice v deltě řeky Niger jim po dlouhé období umožňovala zprostředkovávat obchod mezi Evropany a vnitrozemskými etnickými skupinami jako byli Binijci, Urhhobo nebo Igbo. Př́slušníci kmene Itsekiri v roli obchodních prostředníků profitovali jak z potřeb beninského království, tak z ekonomických zájmů Evropanů. V polovině 90 . let 19. století ale na beninském dvoře narůstala obvinění z podvodů a údajně rostoucího prospěchářství itsekirijských obchodníků. To vedlo beninského obu Ovonramwena k tomu, že v roce 1896 na obchod mezi Itsekiri a beninským královstvím uvalil embargo [Salubi 2007]. Je pravděpodobné, že beninský vladař si uvědomoval, že vnější tlak ze strany kmene Itsekiri a Britů snižuje jeho hegemonii nad jihozápadními teritorii beninského království. Není náhodou, že oba Ovonramwen později uvedl, že „všechny nepř́ijemnosti pocházely od Jekri (Itsekiriů)“ [Home 1982: 20].

Britský konzul James Phillips ale primárně nebojoval za itsekirijské obchodníky, ale za imperiální zájmy Velké Británie. O snaze Britů získat nad Beninským královstvím teritoriální kontrolu ostatně svědčí to, že Protektorát Nigerského pobřeží chtěl provést proti Beninu trestnou výpravu již na počátku roku 1895. Cíl této expedice výstižně dokumentují následující slova: „Pokud se nám podaří získat pozvání, plně jej využijeme ke svému prospěchu a budeme se chovat jako nasákavá houba - jakmile se do země jednou dostaneme, zjistí, jak těžké je se nás znovu zbavit“ [Anene 1966: 179]. Vzhledem k tomu, že právě v tomto roce Benin posílil své jednotky na jižních hranicích a zvýšil vojenskou ostražitost, Koloniální úrrad nedal k připravované vojenské invazi svůj souhlas. James Phillips byl proto nucen při prosazování britských zájmů opět použít diplomatické prostředky. Jednou z možných cest bylo vyvodit důsledky z toho, že beninský oba nedodržoval jeden ze článků smlouvy z roku 1892. Konkrétně následující skutečnost: „Osoby a občané všech zemí mohou volně provozovat obchod v každé části královského teritoria (...)“ [Egharevba 1968: 87]. Phillips byl zpočátku přesvědčen o možnosti dosáhnout svých cílů mírovými prostředky, ale nakonec zjistil, že jeho snaha „jednat v této věci mírovými prostředky (...) nepřinesla očekávané výsledky“ [Phillips 1896]. Proto se v prosinci 1896 rozhodl prosadit britské zájmy v Beninu prostřednictvím nátlakové vojenské mise. Jeho cílem bylo sesadit beninského vládce a nahradit ho místní domorodou správou. Náklady spojené s touto invazí hodlal uhradit slonovinou, nebở věřil, že ji získá v královském paláci. V této souvislosti doslova pronesl: „Mám své důvody věřit, že v královském paláci bude nalezeno dost slonoviny na to, aby se jí pokryly náklady na svržení krále“ [Asante 2012: 171]. Jedním z cílů jeho trestné výpravy do Beninu bylo „přesvědčit krále, aby dovolil bílým mužům vstoupit do města, kdykoli se jim zachce“ [Boisragon 1897: 58]. Oba Ovonramwen ale požádal Phillipse, aby odložil jejich setkání v Beninu o dva měsíce. Phillips však od svého plánu odmítl ustoupit. Neodradila jej ani skutečnost, že právě v období, kdy mělo dojít k jednání s beninským vládcem, probíhá obřadní slavnost ague. $\mathrm{V}$ jejich průběhu přitom nikdo kromě palácových sluhů obu nesměl spatřit. Tento zákaz byl velmi striktní a vztahoval se zejména na cizince.

Phillipsovu vojenskou misi tvořilo osm evropských důstojníků a více než dvě stě neozbrojených afrických vojáků. Důstojníci byli sice ozbrojeni, ale své zbraně měli ukryty v zavazadlech [Egharevba 1960]. Phillips od samého počátku podcenil riziko ozbrojeného střetu a ignoroval varování od spřátelených Itsekiriů. $\mathrm{O}$ to více je paradoxní, že právě jeden 
z obchodních hodnostářu kmene Itsekiri poslal beninskému vládci lakonickou zprávu: „Bílý muž přichází s válkou“ [Roth 1968: xvi]. Oba Ovonramwen ihned svolal své hodnostáře, aby společně zvážili možná řešení dané situace. Velitel beninské armády (iyase) označil britský postup za akt násilí a agresivní pokus o náhlý vojenský útok. Oba zvažoval možnost povolit Britům vstup do města a tak zjistit, nakolik se jedná o přátelskou, nebo naopak nepřátelskou misi. Velitel beninské armády ale snahu beninského vládce o hledání mírového řešení nerespektoval. Nařídil zformovat beninské vojenské úderné síly, jejímž velením pověřil ologbose (starší velitel armády). Ten vyrazil do Ugbine poblíž Gwato s cílem zničit britskou expedici.

James Phillips údajně včas podal beninskému vladaři zprávu, že členové jeho mise jsou neozbrojeni. Tato informace ale nic nezměnila na tom, že dne 4 . ledna 1897 v odpoledních hodinách beninské jednotky tvořené členy pohraniční stráže a služebníky hodnostářů napadly britskou expedici v Ugbine [Geary 1927]. Phillips zemřel jako první poté, co pronesl: „Žádné zbraně, pánové!“ [Boisragon 1897: 101]. Přepadení Phillipsovy expedice přežilo pouze několik vojáků a dva britští důstojníci, kapitán Alan Maxwell Boisragon (1860-1922) a Ralph Frederick Locke (1865-1933). Oba Ovonramwen vojenské likvidace britského oddílu litoval, nebot tušil, že za tuto událost bude jeho země tvrdě potrestána. Ve snaze odvrátit britskou válečnou odvetu požádal o prrízeň božských předků tradičním rituálním způsobem prostřednictvím obětí. V té době ale již generální britský konzul Ralph Denham Rayment Moor (1860-1909) spěchal z Velké Británie do Beninu vyhlásit tomuto království válku.

Dne 12. ledna 1897 se ujal organizace trestné vojenské výpravy proti beninskému království Harry Rawson (1843-1910). Velením pozemního vojska byli v průběhu britské expedice pověřeni Reginald H. Bacon, Bruce Meade Hamilton a Henry Lionel Gallwey. Cílem výpravy bylo ničit beninská města a vesnice, dobýt město Benin, zajmout obu Ovonramwena a oběsit ho. Invazi provedlo 1200 vojáků [Bacon 1897]. Jednotky byly složeny z britské pěchoty, námořníků a vojáků Protektorátu Nigerského pobřeží. Pochodu na město Benin se zúčastnili též domorodí zvědové. Rawson rozdělil expediční armádu do tří vojenských oddílů, které zaútočily na strategické cíle v Sapoba, Gwato a Ologbo [Grant Atteridge 1899; Bacon 1925; Roth 1968]. Námořní vojsko napadlo Gwato na západě a Sapoba na řece Jamieson východně od hlavního města. Nejkratší cestu do města Benin měl hlavní oddíl, jež obsadil Ologbo. První podpůrný oddíl operující na západě se zaměřil na Binijce bránící cesty z Gwato do Beninu. Druhý opěrný oddíl operující na východě měl za úkol bránit útěku obyvatel města Benin do pokojných oblastí. Dne 11. února bylo vše připraveno k útoku. Již dne 15. února hlavní oddíl, který nechal za svými zády Ologbo, dosáhl Agagi, a vzápětí již 18. února Igba, jež se nachází necelé dva kilometry od Beninu. Ještě týž den vstoupily britské jednotky za zvuku kulometné palby do města Benin a definitivně tak ukončily nezávislost beninského království [Eardley-Wilmot 1899].

Beninský král, jeho hodnostáři a většina obyvatel ale své město opustili ještě před příchodem britské armády. Na útěku se ocitli dokonce beninští kněží (juju) praktikující tradiční magii. Britové, kteří si postavili svůj hlavní stan v obově paláci, byli z podivné atmosféry, jež zánik Beninu doprovázela, velmi zmatení. „Před dveřmi domů a před branami budov byl cítit zápach koz a drůbeže, obětovaných patrně za účelem, aby do města nevstoupil bílý muž“ [Geary 1927: 117]. V touze zabránit dobytí města sáhli Binijci k lidským obětem, jejichž pozůstatky vojáci nacházeli na každém kroku. „Celé město čpí lidskou krví, vždyt těla mnoha obětovaných a ukřižovaných byla nalezena rozeseta ve všech 
jeho částech“ [Hernon 2000: 170]. Mrtvá a rozkládající se těla vydávala „tak nepř́ijemný zápach, že téměř všichni důstojníci a mužstvo při svém prvním př́ijezdu do města trpěli silným nechutenstvím“ [Boisragon 1897: 164]. Navzdory rituálním opatřením obránci Beninu dobytí svého města a následného rabování nezabránili. Britští vojáci nemuseli po své kořisti příliš pátrat. Na nádvoří královského paláce ihned narazili na desítky bronzových reliéfních desek. Překrásná výtvarná díla vyrobená z bronzu, dřeva nebo ze slonoviny se nacházela také v palácových interiérech. Dobytí Beninu ale nebylo spojené pouze s rabováním. Důsledkem invaze byla také likvidace původní beninské architektury. $\mathrm{Z}$ důvodů lepšího zabezpečení obrany paláce byla část domů vojáky zničena. Osudový však byl požár, který se vymkl kontrole a pohltil palác i část města. ${ }^{3}$ Vypleněné město hořelo pět dní. Palác byl evakuován ve velkém spěchu, a tak se stalo, že mnoho uměleckých artefaktů bylo nevratně zničeno [Bacon 1897; Roth 1968]. Navzdory tomu byla kořist, jejímž prodejem chtěli Britové uhradit náklady válečné výpravy, doslova monumentální. Do Velké Británie bylo dopraveno 2400 beninských uměleckých děl, z nichž bylo velké množství prodáno v dražbě. Rawson po úspěšné invazi předal správu bývalého beninského království pod britskou koloniální správu, jejíž reprezentanti krátce poté konstatovali, že tato surovinově bohatá země byla konečně zpřístupněna vlivu západní civilizace a volného obchodu. Poměrně v krátkém období se export navýšil o $25 \%$. Koncepce dalšího rozvoje beninského teritoria v sobě zahrnovala evropský př́slib Africe - rozvoj dopravy, rozšíření infrastruktury, posílení měny a udržování řádu [Helleiner 1966]. Benin se nevratně ocitl spoutaný sítí britských obchodních, politických a ekonomických zájmů.

Pád Beninu i jeho další osud předpověděl krátce před svou popravou jorubský obchodník Thompson Oyibodudu. K obětování tohoto muže došlo v průběhu obřadu ugie ivie. Důvodem bylo to, že porušil beninská obchodní omezení. Krátce předtím, než mu popravčí setnul hlavu, údajně pronesl: „Bílí muži, kteří jsou vyspělejší víc než vy nebo já, jdou s vámi bojovat a zmocnit se vás" [Home 1982: 17]. Z britské perspektivy komentoval krvavé rituály, k nimž se v zoufalství Binijci uchýlili, jeden z anglických velitelů Reginald H. Bacon: „Krev byla všude; byl jí potřísněn bronz, slonovina, ba i zdi a svědčila o historii tohoto strašného města mnohem výmluvněji, než by bylo možné slovy popsat. A taková historie se opakovaně odehrávala po staletí!“ [1897: 89].

\section{Evropská reflexe britské invaze a pádu království Benin}

Zprávy o dobytí Beninu, spojené s prezentací beninských artefaktů, vyvolaly v Evropě velmi rozporuplné reakce. Ty obsahovaly široké spektrum postojů zahrnující jak pozitivní fascinaci nadčasovým africkým uměním, tak hororovou hrůzu vyvolanou informacemi o existenci exotické říše vyznávající kult obětí a krve. Britskou veřejnost beninská umělecká díla překvapila svojí tvořivou imaginativností, výtvarnou krásou a technickou dokonalostí.

\footnotetext{
3 Podle domněnek a zpráv v soudobém tisku Illustrierte Zeitung (28. 5. 1898) požár úmyslně způsobili Binijci. Chtěli totiž využít vzniklého chaosu, aby získali bronzové desky uskladněné v paláci a transportovali je do úkrytu mimo území města. Dodnes však nebyla příčina přesně určena. Binijci přepokládají, že oheň způsobili britští útočníci [Eyo 1997]. Popisy účastníků britské expedice však dokládají, že oheň byl neočekávaný. V této části paláce se navíc nacházelo vybavení a v blízkosti záchranná vojenská nemocnice, ve spěchu evakuovaná [Boisragon 1897]. Některé názory připouští, že oheň propukl v důsledku nepozornosti dvou opilých vojáků [Home 1982].
} 
Dokud Evropané nestanuli tváŕí v tvář beninským bronzům, považovali Benin a jeho obyvatele za ztělesnění hrůzy a exotického primitivismu. Benin byl pro ně královstvím hříchů, v jehož čele stál barbarský král, který vědomě odmítal hodnoty západní civilizace a byl za to oprávněně Brity potrestán ztrátou své říše. Také Binijce Evropané nepovažovali za rovnocenné partnery, nýbrž za „degradovanou rasu“ a reprezentanty „degenerované kultury“ [Coombes 1994; Kowaleski-Wallace 2006]. Z pohledu západní civilizace, hodnotící cizí kulturu z perspektivy evropocentrismu, bylo vyvrácení Beninu chápáno jako civilizovaný akt osvobození beninských obyvatel z teroru, hrůzy a strachu, který zde v minulosti šírili krutí beninští vládci.

Týdeník Illustrated London News věnoval dobytí Beninu speciální suplement Beninská expedice: skici pana H. C. Seppings Wrighta, našeho umělce z expediční armády, ${ }^{4}$ publikovaný 27. března 1897 [Roth 1968]. Ilustracemi jej doprovodil válečný dopisovatel a ilustrátor Henry Charles Seppings Wright (1850-1937), který do města vstoupil 21. ledna 1897 a ihned začal dokumentovat následky invaze [Bacon 1897; Geary 1997]. Benin alegoricky zobrazil jako barbarskou africkou Golgotu pokrytou mrtvými těly rituálně usmrcených lidských obětí. Tyto nelidské obrazy ilustrující utrpení obětovaných otroků beninského vládce programově stavěl do kontrastu se scénami zobrazujícími každodenní život britských vojáků. Tento interpretativní model, pozitivně prezentující britskou invazi jako misi „civilizovaných“ osvoboditelů, byl uplatněn také v dubnu 1897, kdy byly v britském týdeníku The Graphic publikovány kresby. Ty zachycují několik britských vojáků, kteří se, unavení den po invazi, mírumilovně koupou v zátoce. Podobné ilustrace se v různých verzích a tematických variantách staly součástí širokého spektra populárních i vědeckých publikací na téma dobytí království Benin a byly považovány za objektivní vizuální dokumentaci [Coombes 1994]. Zprávy o britské invazi do Beninu byly uveřejněny také v německém tisku. Zde převažovaly informace o ctižádosti Phillipse a dobytí Beninu bylo interpretováno jako skrytá strategie umožňující zabezpečit britskou nadvládu v regionu. Např́klad podle berlínských novin Vossische Zeitung bylo dobytí Beninu jedním z mnoha kroků směřujících k prosazení britských koloniálních zájmů.

Součástí konfrontace západní civilizace a beninského království se staly také beninské umělecké předměty. Tyto artefakty uloupené britskou expediční armádou byly v britském tisku označovány jako relikvie (relics), v německém tisku jako starožitnosti (Altertümer) [Pitt-Rivers 1900; Luschan 1919]. Užití těchto pojmů odráželo dobové přesvědčení, podle něhož mohly být kovodělné artefakty „relikviemi bývalé vyšší civilizace“, nebo dokonce „kořistí nějaké výpravy“. Na výtvarnou kvalitu beninských bronzů a řezeb do slonoviny se důrazně upozorňovalo v několika zprávách. Uměleckou hodnotu těchto artefaktů ovšem v očích Evropanů snižovalo jejich spojení s krvavými beninskými rituály a přesvědčením, že na artefakty nalezené ve „městě krve“ se vztahuje prokletí [Bacon 1897].

Bezprostřední vzrušení a senzaci vyvolalo beninské umění až krátce poté, co bylo poprvé ${ }^{5}$ oficiálně prezentováno prostřednictvím aukcí a výstav v Evropě, konaných

4 Originální název The Benin Expedition: Sketches by Mr. H. C. Seppings Wright, our Artist with the Expeditionary Force.

5 Beninské artefakty pronikaly do Evropy jako součást obchodu Beninu s Evropany. Například britský obchodník John H. Swainson obdržel v roce 1892 od beninského krále darem bronzovou plastiku koně. Beninská výtvarná díla, která se ocitla v Evropě, ale byla zpočátku většinou mylně považována za výtvory, které mají indický, turecký, mexický nebo dokonce sibiřský původ, anebo vznikla v románském a gotickém období. 
nejdříve ve Velké Británii a následně pak v Německu. Britská expediční armáda, která v roce 1897 vyrabovala město Benin, odtud přivezla více než $2400^{6}$ uměleckých artefaktů odlitých z bronzu nebo vyřezaných ze slonoviny či ze dřeva. Tato unikátní vojenská kořist byla rozprodána $\mathrm{v}$ aukcích a dnes je ozdobou řady evropských i amerických uměleckých sbírek. Uloupené beninské artefakty, vystavené v prostředí západních muzeí, etnologických sbírek a uměleckých výstavních síní, sehrály významnou roli v tom, že Evropané postupně začali pozitivně měnit svůj přístup k vnímání, hodnocení i interpretaci domorodého afrického umění [Luschan 1919]. Beninské umění začalo aktivně ovlivňovat tvorbu západních umělců a vytvářet stále větší transkulturní vliv na estetické vnímání v dílech moderních umělců.

Původně byly beninské artefakty považovány spíše za válečnou kořist nežli za hodnotná výtvarná díla, tajuplné vzácné poklady nebo africké dvorské umění. Od chvíle, kdy se tato díla stala oceňovanou součástí světových sbírek, se radikálně změnilo i jejich hodnocení. Některé beninské bronzy z 16. století byly z hlediska svého uměleckého a technologického zpracování oceňovány dokonce více nežli analogická dobová evropská produkce bronzových předmětů. Ve druhé polovině 20. století se přední světová muzea, v jejichž sbírkách se beninské artefakty nacházely, stále více věnovala prezentaci těchto děl na výstavách, v katalozích, odborných studiích i článcích v populárních časopisech určených široké veřejnosti. Navzdory rasistickým nebo etnocentrickým ústrkům beninské bronzy a další umělecká díla získaly pevnou pozici na tržním i uměleckém poli. „Beninské artefakty vstoupily na mezinárodní trh v tichosti; brzy se kolem nich strhla bouře..." [Penny 2002: 71].

\section{Literatura}

Allman, Robert [1898]. With the Punitive Expedition in Benin City. The Lancet 2: 43-44.

Anene, Joseph C. [1966]. Southern Nigeria in Transition, 1885-1906. Theory and Practice in a Colonial Protectorate. Cambridge: Cambridge University Press.

Aniakor, Chike Cyril [1978]. Igbo Architecture: A Study of Forms, Functions and Typology I. Dissertation. Bloomington: Indiana University.

Asante, Molefi Kete [2012]. The History of Africa: The Quest for Eternal Harmony. New York: Routledge. Bacon, Reginald Hugh [1897]. Benin: The City of Blood. London: Edward Arnold.

Bacon, Reginald Hugh Spencer [1925]. A Naval Scrap-Book. First Part, 1877-1900. London: Hutchinson. Ben-Amos, Paula [1995]. The Art of Benin. London: British Museum Press.

Birmingham, David [2010]. Trade and Empire in the Atlantic, 1400-1600. New York: Routledge.

Boisragon, Alan [1897]. The Benin Massacre. London: Methuen \& Co.

Burton, Richard Francis [1863]. My Wanderings in West Africa: A Visit to the Renowned Cities of Wari and Benin. Fraser's Magazine 67: 135-157, 273-289, 407-422.

Coombes, Annie E. [1994]. Reinventing Africa: Museums, Material Culture and Popular Imagination in Late Victorian and Edwardian England. New Haven, London: Yale University Press.

Connah, Graham [1972]. Archaeology in Benin. The Journal of African History 13 (1): 25-38.

6 Dodnes není známý přesný počet beninských artefaktů. Felix von Luschan uvádí 2400, zatímco Philip Dark odhaduje až 6500 kusů. Nepoměr je zpo̊soben tím, že Dark do svých výpočtů zahrnuje i artefakty, jež se staly součástí muzeí a soukromých sbírek ještě v průběhu 20. století. Luschan uvádí pouze počty artefaktů, které byly dovezeny do Evropy jako kořist britské invaze. 
Connah, Graham [1975]. The Archaeology of Benin: Excavations and Other Researches in and Around Benin City, Nigeria. Oxford: Clarendon Press.

Curley, Robert (ed.) [2012]. Explorers of the Renaissance. New York: Britannica Educational Publishing.

Curnow, Kathy [2007]. Cultural Flow and Cultural Breakwaters: Art Connecting the Benin Kingdom with the Coast. In. Plankensteiner, Barbara (ed.). Benin: Kings and Rituals. Court Arts from Nigeria. Gent: Snoeck, s. 171-184.

Curtin, Philip D. [1969]. The Atlantic Slave Trade: A Census. Madison: University of Wisconsin Press.

Dark, Philip J. C. [1973]. An Introduction to Benin Art and Technology. Oxford: Clarendon Press.

Darling, Patrick J. [1976]. Notes on the Earthworks of the Benin Empire. West African Journal of Archaeology 6: 143-149.

Darling, Patrick J. [1998]. A Legacy in Earth: Ancient Benin and Ishan, Southern Nigeria. In. Wesler, Kit W. (ed.). Historical archaeology in Nigeria. Trenton: Africa World Press, s. 143-197.

Davidson, Basil [1962]. Objevení staré Afriky. Praha: Mladá fronta.

Dmochowski, Zbigniew R. [1990]. An Introduction to Nigerian Traditional Architecture II: South-West and Central Nigeria. London: Ethnographica.

Eardley-Wilmot, Sydney Marow [1899]. Our Navy for a Thousand Years: A Concise Account of all the Principal Operations in Which the British Navy Has Been Engaged From the Time of King Alfred to the Recapture of Khartoum. London: S. Low, Marston.

Egharevba, Jacob U. [1968]. A Short History of Benin. Ibadan: Ibadan University Press.

Ekeh, Peter P. [2007]. History of the Urhobo People of Niger Delta. Buffalo: Urhobo Historical Society.

Euba, Titiola [1981]. Of Blue Beads and Red: The Role of Ife in the West African Trade in Kori Beads. Journal of the Historical Society of Nigeria 11 (1-2): 109-127.

Eyo, Ekpo [1997]. The Dialectics of Definitions: "Massacre" and "Sack" in the History of the Punitive Expedition. African Arts 30 (3): 34-35.

Falola, Toyin [2002]. Key Events in African History: A Reference Guide. Conn: Greenwood.

Falola, Toyin [2009]. Colonialism and Violence in Nigeria. Bloomington: Indiana University Press.

Feinberg, Harvey M. [1989]. The Europeans in West Africa: Culture Contact, Continuity and Change. Philadelphia: American Philosophical Society.

Gallwey, Henry L. [1893]. Journeys in the Benin Country, West Africa. Journal of the Royal Geographical Society 1 (2): 122-130.

Gallwey, Henry [1930]. Nigeria in the "Nineties". Journal of the African Society 29 (115): 221-247.

Geary, William Nevill Montgomerie [1927]. Nigeria Under British Rule. London: Methuen \& Company Limited.

Gore, Charles [2007]. Art, Performance and Ritual in Benin City. Edinburgh: Edinburgh University Press for the International African Institute, London.

Grant, James - Atteridge, A. Hilliard [1899]. British Battles on Land and Sea. London: Cassell \& Co.

Hargreaves, John D. [1974]. West Africa Partitioned I. London, Basingstoke: Macmillan Press.

Helleiner, Gerald K. [1966]. Peasant Agriculture, Government and Economic Growth in Nigeria. Illinois: Richard D. Irwin.

Hernon, Ian [2000]. The Savage Empire: Wars of the 19th Century. Stroud: Sutton Publishing.

Home, Robert [1982]. City of Blood Revisited: A New Look at the Benin Expedition of 1897. London: Lex Collins.

Igbafe, Philip Aigbona [1970]. The Fall of Benin: A Reassessment. The Journal of African History 11 (3): 385-400.

Igbafe, Philip Aigbona [1980]. The Precolonial Economic Foundations of the Benin Kingdom. In. Akinjogbin, Isaac Adeagbo - Osoba, Segun (eds.). Topics on Nigerian Economic and Social History. Ile-Ife: University of Ife Press, s. 19-34.

Iliffe, John [2001]. Afrika a Afričané: dějiny kontinentu. Praha: Vyšehrad.

Kilger, Laurenz [1932]. Die Missionsversuche in Benin. Zeitschrift für Missions- und Religionswissenschaft 22: 305-319.

Kingsley, Mary [2010]. West African Studies. Cambridge: Cambridge University Press.

Kowaleski-Wallace, Elizabeth [2006]. The British Slave Trade and Public Memory. New York: Columbia University Press.

Kriger, Colleen E. [2006]. Cloth in West African History. Lanham: AltaMira Press. 
Law, Robin [2002]. From Slave Trade to "Legitimate" Commerce: The Commercial. Cambridge: Cambridge University Press.

Lovejoy, Paul E. [2004]. The Yoruba Factor in the Trans-Atlantic Slave Trade. In. Falola, Toyin - Child, Matt D. (eds.). The Yoruba Diaspora in the Atlantic World: Methodology and Research. Indianapolis: Indiana University Press, s. 40-55.

Lovell, Mary S. [1998]. A Rage to Live: A Biography of Richard and Isabel Burton. New York: W. W. Norton \& Company.

Luschan, Felix von [1919]. Die Altertümer von Benin I-III. Berlin, Leipzig: Vereinigung Wissenschaftlicher Verleger Walter de Gruyter.

Lynn, Martin [1998]. Commerce and Economic Change in West Africa: The Palm Oil Trade in the Nineteenth Century. Cambridge: Cambridge University Press.

Macdonald, Claude Maxwell [1893]. Private letters from MacDonald to Rosebery. National Archives of the United Kingdom, FO 2/51. January 12, 1893.

Nevadomsky, Joseph [2006]. Punitive Expedition Photographs from the British Army Museum and the Parody of the Benin Kingdom in the Time of Empire. Archiv für Völkerkunde 56: 43-50.

Newbury, Colin Walter [1971]. British Policy Towards West Africa: Select Documents 1875-1914. Oxford: Clarendon Press.

Newitt, Malyn [2005]. A History of Portuguese Overseas Expansion, 1400-1668. New York: Routledge.

Newitt, Malyn [2010]. The Portuguese in West Africa, 1415-1670: A Documentary History. New York: Cambridge University Press.

Omoerha, Thompson [1975]. Edo Studies: A Preliminary Bibliography. Benin City: Benin University Library.

Oriaifo, S. O. - Gbenedio, Uche B. [1992]. Towards Education in Nigeria for the Twenty-First Century. Benin City: Institut of Education, University of Benin.

Payne, John [2011]. Universal Geography Formed Into a New and Entire System: Describing Asia, Africa, Europe, and America ... to Which is Added, a Short View of Astronomy. Charleston: Nabu Press.

Penny, Glenn [2002]. Objects of Culture: Ethnology and Ethnographic Museums in Imperial Germany. Chapel Hill: University of North Carolina Press.

Pereira, Duarte Pacheco [1967]. Esmeraldo de situ orbis. Nendeln: Kraus.

Phillips, James [1896]. Phillips to Under-Secretary of State. National Archives of the United Kingdom, FO 2/102. November 16, 1896.

Pitt-Rivers, Augustus Henry Lane-Fox [1900]. Antique Works of Art from Benin. London: Harrison and Sons.

Porter, Andrew Neil [1994]. Atlas of British Overseas Expansion. London: Routledge.

Roth, Henry Ling [1903]. Great Benin: Its Customs, Art and Horrors. Halifax: F. King \& Sons.

Roth, Henry Ling [1968]. Great Benin: Its Customs, Art and Horrors. London: Routledge and Kegan Paul. Ryder, Alan Frederick Charles [1969]. Benin and the Europeans, 1485-1897. London: Longmans.

Salubi, Thompson Edogbeji Aitkins [2005]. Perspectives on Itsekiri History and the Title of the Itsekiri King. In. Ekeh, Peter Palmer (ed.). Warri City and British Colonial Rule in Western Niger Delta. Lagos: Urhobo Historical Society, s. 72-104.

Salubi, Thompson Edogbeji Aitkins [2007]. The Establishment of British Administration in Urhobo Country, 1891-1913. In. Ekeh, Peter Palmer (ed.). History of the Urhobo People of Niger Delta. Buffalo: Urhobo Historical Society, s. 67-85.

Skinner, Elliott Percival [1973]. Peoples and Cultures of Africa: An Anthropological Reader. New York: Natural History Press.

Sundström, Lars [1974]. Exchange Economy of Pre-Colonial Tropical Africa. London: Hurst.

Talbot, Percy Amaury [1926]. The Peoples of Southern Nigeria: A Sketch of Their History, Ethnology, and Languages, with an Abstract of the 1921 Census I.-IV. London: F. Cass.

Thompson, Leonard [1990]. A History of South Africa. New Haven: Yale University Press.

Walker, Robin [2006]. When We Ruled: The Ancient and Medieval History of Black Civilisations. London: Every Generation Media. 
Barbora Půtová je historička umění a antropoložka pưsobící na Filozofické fakultě Univerzity Karlovy v Praze. Zabývá se antropologií umění, historickou antropologií, výzkumy pravěkého a skalního umění. Je autorkou mj. monografií Pravěké umění: evoluce člověka a kultury (2011, spoluautoři J. Clottes a V. Soukup), Kristkova Podyjská glyptotéka (2013) a Félicien Rops: enfant terrible dekadence (2013). Průběžně publikuje studie věnované umění 19. století a je aktivní také jako kurátorka.

Václav Soukup vyučuje sociokulturní antropologii na Filozofické fakultě Univerzity Karlovy v Praze. Ve své výzkumné, publikační a pedagogické činnosti se zaměruje na sociální a kulturní antropologii, paleoantropologii a teorii kultury. Vydal řadu odborných studií a monografí. Jeho kniha Dějiny antropologie (2004) byla ocenèna Cenou rektora Univerzity Karlovy jako nejlepší publikace v oblasti společenských věd za rok 2004. Jeho rozsáhlé antropologické kompendium Antropologie: teorie člověka a kultury (2011) představuje komplexní uvedení do biologické a kulturní antropologie. 